\title{
BRPKM
}

Buletin Riset Psikologi dan Kesehatan Mental

http://e-journal.unair.ac.id/index.php/BRPKM

e-ISSN: 2776-1851

ARTIKEL PENELITIAN

\section{Hubungan antara Kecenderungan Alexithymia dengan Agresivitas pada Usia Remaja}

VICTORIA CINDY \& TRI KURNIATI AMBARINI*

Fakultas Psikologi Universitas Airlangga

\begin{abstract}
ABSTRAK
Prevalensi kekerasan remaja yang tinggi pada beberapa tahun terakhir menunjukkan seriusnya permasalahan agresivitas dalam kehidupan remaja. Agresivitas pada remaja seringkali terjadi karena dipengaruhi oleh masalah emosional, seperti kurangnya kesadaran emosi dan kesulitan mengekspresikan emosi yakni alexithymia. Penelitian ini bertujuan untuk mengetahui apakah terdapat hubungan antara alexithymia dan agresivitas pada usia remaja. Penelitian ini dilakukan pada 206 remaja berusia 12-19 tahun yang tidak mengonsumsi narkoba/alkohol dalam sebulan terakhir. Penelitian ini menggunakan skala agresi (BPAQ-29) dan skala alexithymia (TAS-20). Uji korelasi menunjukkan terdapat hubungan signifikan antara alexithymia dan agresivitas pada usia remaja, $r(204)=0,41, p=$ 0,000. Persentase tertinggi variabel alexithymia pada remaja berada pada skor tertinggi, sedangkan persentase tertinggi variabel agresivitas berada pada skor moderat. Hasil penelitian ini mengimplikasikan adanya masalah emosi dan agresi pada usia remaja yang cukup tinggi sehingga perlu pencegahan masalah mental yang lebih parah bagi remaja di kemudian hari.
\end{abstract}

Kata kunci: agresivitas, alexithymia, remaja

\section{ABSTRACT}

The high prevalence of adolescent violence demonstrates the seriousness of aggressiveness in adolescents. Adolescent violence often results from emotional problems, such as lack of emotional awareness or difficulty expressing emotions called alexithymia. This study aims to examine the relationship between alexithymia and aggressiveness in adolescence. This study was conducted on 206 adolescents aged 12-19 years who had not consumed drugs/alcohol in the last month. This study used the aggression scale (BPAQ-29) and the alexithymia scale (TAS-20). Correlation tests showed a significant relationship between alexithymia and aggressiveness in adolescents, $r(204)=0.41, p=0.000$. The highest percentage of alexithymia was at the highest score, while the highest percentage of aggressiveness was on moderate scores. The results of this study imply considerable emotional and aggression problems in adolescence so preventions of more severe adolescent mental problems in later life are needed.

Keywords: adolescents, aggressiveness, alexithymia

Buletin Penelitian Psikologi dan Kesehatan Mental (BRPKM), 2021, Vol. 1(1), 678-694

*Alamat korespondensi: Fakultas Psikologi Universitas Airlangga, Kampus B Universitas Airlangga Jalan

Airlangga 4-6 Surabaya 60286. Surel: tri.ambarini@psikologi.unair.ac.id 
Naskah ini merupakan naskah dengan akses terbuka dibawah ketentuan the Creative Common Attribution License (CC-BY-4.0) (http://creativecommons.org/licenses/by/4.0), sehingga penggunaan, distribusi, reproduksi dalam media apapun atas artikel ini tidak dibatasi, selama sumber aslinya disitir dengan baik.

\section{PENDAH U L UA N}

Prevalensi kekerasan yang tinggi pada beberapa tahun terakhir menunjukkan seriusnya permasalahan agresivitas dalam kehidupan masyarakat. Sistem Nasional Pemantauan Kekerasan Indonesia (SNPK) pada tahun 2015 menunjukkan terjadinya insiden kekerasan sebanyak 2.027 kasus di 34 provinsi di Indonesia. Dampak dari kekerasan tersebut menyebabkan sebanyak 216 orang tewas dan 1.690 orang cedera. Agresivitas yang terjadi pada individu erat kaitannya dengan proses emosional (Nurfitria \& Machsunah, 2019; Teten, dkk., 2008). Menurut Rinanda \& Haryanta (2017), agresi merupakan bentuk luapan emosi negatif yang tidak dapat dikontrol, seperti rasa frustrasi dan amarah disertai rasa tidak suka yang kuat. Akan tetapi, penelitian selanjutnya menyatakan adanya masalah dalam fungsi emosional juga dapat menyebabkan munculnya agresivitas, seperti rendahnya kesadaran emosi (Aeni, 2011; Gillespie, dkk., 2018; Merdekasari \& Chaer, 2017; Roberton, dkk., 2012). Contohnya ketika individu memberikan respon secara tiba-tiba terhadap situasi yang memicu emosi negatif.

Kondisi di atas dapat ditemukan pada masa remaja yang seringkali ditandai dengan adanya pergolakan dan ketidakstabilan emosi jika dibandingkan dengan usia dewasa. Walgito (2005, dalam Fitri \& Adelya, 2017) juga menyatakan bahwa remaja memang memiliki kemampuan emosi yang berbeda-beda, namun umumnya tingkah laku remaja seringkali sulit dipahami dan diterima dengan pikiran yang baik karena kurang menguasai dan mengendalikan emosi sehingga dapat dikatakan bahwa kemampuan emosi remaja tersebut belum terbentuk dengan baik (Fitri \& Adelya, 2017). Keadaan emosi ini terkadang membuat remaja cenderung mudah terbawa emosi negatif, memiliki kesabaran yang rendah, mudah tersinggung, cenderung memaksakan pendapat, dan merasa perlu bertindak agresif apabila ingin menyelesaikan perkara. Hal tersebut disebabkan karena rendahnya kemampuannya untuk mengetahui, memahami, dan merasakan emosi, serta bertoleransi dan menjalin pertemanan dengan orang lain (Merdekasari \& Chaer, 2017). Oleh karena itu, kondisi emosi yang dialami remaja tersebut dapat menggambarkan karakteristik utama dari alexithymia yakni defisit kognitif dalam mengidentifikasi dan mengungkapkan emosi, serta kurang memikirkan emosi yang dirasakan. Moriguchi dan kawan-kawan (2007, dalam Ng \& Chan, 2020) menyatakan bahwa kemampuan kognitif seseorang untuk mengenali dan mengontrol emosi diperoleh selama perkembangan dan kegagalan untuk mencapai hal tersebut dapat berhubungan dengan alexithymia.

Alexithymia karakteristik kepribadian atau trait berupa defisit kognitif dalam mengidentifikasi dan mengkomunikasikan emosi, serta rendahnya pikiran akan emosi (Jenkins, 2018; Taylor, dkk., 1999). Gohm dan Clore (2002, dalam Winter, dkk., 2017) dan Mahapatra dan Sharma (2018, dalam Janik McErlean \& Lim, 2019) menemukan bahwa berkurangnya kapasitas untuk mengidentifikasi dan mengungkapkan emosi seperti yang terdapat pada alexithymia cenderung membuat individu mengalami distress psikologis dan melakukan gaya koping yang maladaptif untuk pengungkapan emosinya. Berkurangnya kapasitas untuk mengidentifikasi emosi cenderung membuat individu mengalami distres psikologis dan melakukan gaya koping yang maladaptif untuk meregulasi emosinya sehingga memiliki masalah dalam keberfungsian sosial (Jenkins, 2018). Penelitian sebelumnya juga menemukan bahwa prevalensi alexithymia pada populasi umum yang dapat meningkat pada individuindividu yang agresif (Winter, dkk., 2017). 
Beberapa penelitian telah mengkonfirmasi hal tersebut, akan tetapi terdapat pula penelitian lain yang menemukan hal yang sedikit berlawanan. Penelitian oleh Evren, dkk. (2015) menemukan individu dengan alexithymia memiliki tingkat agresi yang lebih tinggi dibandingkan individu non-alexithymia. Penelitian Janik McErlean \& Lim (2019) dan Li, dkk (2020) juga menemukan bahwa terdapat hubungan positif antara alexithymia dan agresi. Sebaliknya, de Schutter, dkk. (2016) menemukan bahwa peningkatan level alexithymia tidak terkait dengan level agresivitas yang lebih tinggi. Alasannya karena individu yang lebih sadar secara emosi dapat memberikan respon stres yang lebih tinggi terhadap stimulus ancaman sehingga rentan akan pikiran dan emosi negatif. Studi literatur oleh Hemming, dkk. (2019) juga menyebutkan adanya sedikit asosiasi antara agresivitas dengan karakteristik alexithymia yaitu gaya berpikir konkrit dimana individu mengabaikan emosi dalam diri. Disebutkan bahwa mengabaikan emosi dalam diri memungkinkan seseorang untuk melindungi kondisi mental dari efek buruk seperti menyalahkan diri sendiri, meskipun juga tidak memungkinkan untuk melakukan penilaian ulang terhadap suatu masalah (Larionov \& Grechukha, 2020).

Berdasarkan pembahasan di atas, studi lebih lanjut diperlukan untuk menguji keterkaitan antara kemampuan individu dalam memahami dan mengungkapkan emosi dengan kemunculan tindakan agresif oleh individu, khususnya bagi remaja yang masih memiliki emosi yang labil. Penelitian mengenai topik ini sendiri masih belum banyak ditemui dalam konteks kultural masyarakat kolektif di Indonesia. Penelitian ini juga penting dilaksanakan untuk mengidentifikasi masalah perilaku pada remaja yang dapat berperan sebagai faktor risiko kemunculan masalah psikologis pada usia dewasa.

\section{Desain Penelitian}

\section{E T O D E}

Tujuan penelitian ialah untuk menguji korelasi atau hubungan antara alexithymia dan agresivitas pada remaja sehingga tipe penelitian kuantitatif korelasional akan digunakan sebagai metode penelitian. Penelitian kuantitatif korelasional bertujuan untuk menggambarkan kekuatan relasi antara dua variabel, yang akan dianalisis secara statistik dan dapat dilihat melalui koefisien korelasi. Penelitian dilakukan melalui survei atau kuesioner yang bertujuan mengakses pikiran, pendapat, dan perasaan orang partisipan penelitian (Merdekasari \& Chaer, 2017). Penelitian akan dilakukan dalam bentuk crosssectional design, dimana sampel diambil dari populasi pada satu waktu yang sama.

\section{Partisipan}

Penelitian ini menggunakan teknik purposive sampling sehingga menggunakan beberapa pertimbangan tertentu seperti adanya ciri-ciri yang sama pada populasi, ataupun memilih beberapa sampel tertentu yang dinilai akan sesuai dengan masalah penelitian. Partisipan penelitian ini ialah remaja berusia 12-19 tahun dan tidak sedang mengonsumsi narkoba atau alkohol setidaknya dalam 1 bulan terakhir. Penentuan jumlah sampel menggunakan bantuan software GPower 3.1 dengan effect size atau $r=0.25$, level signifikansi atau $\alpha=0.05$, dan nilai statistical power atau $(1-\beta)=0,95$ atau $95 \%$. Dengan demikian, sampel minimal yang dibutuhkan untuk populasi remaja ialah 202 orang. Sebelum mengisi kuesioner penelitian, partisipan diberikan lembar informed consent sebagai bukti kesediaan berpartisipasi dalam penelitian.

Data demografis menunjukkan jumlah partisipan dalam penelitian ini berjumlah $N=206$ orang. Partisipan berjenis kelamin perempuan berjumlah 160 orang $(77,7 \%)$, sedangkan partisipan berjenis

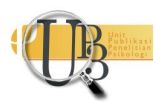


kelamin laki-laki berjumlah 46 orang (22,3\%). Sehingga, jumlah perempuan yang berpartisipasi dalam penelitian ini lebih banyak dibandingkan laki-laki. Selanjutnya, frekuensi usia tertinggi dari keseluruhan sampel ialah partisipan berusia 19 tahun yang berjumlah 57 orang $\left(M_{\text {usia }}=17,11 ; S D_{\text {usia }}=1,890 ; 27,7 \%\right)$.

\section{Pengukuran}

Teknik pengumpulan data dalam penelitian ini menggunakan kuesioner self-report mencakup informasi mengenai identitas partisipan dan skala Likert yang sudah diterjemahkan ke dalam Bahasa Indonesia. Kuesioner yang dipakai untuk mengukur alexithymia adalah the Toronto Alexithymia Scale-20 (TAS-20) oleh Taylor, dkk. (1999). TAS-20 dianggap sebagai alat ukur terbaik alexithymia dengan reliabilitas dan validitas yang baik. Peneliti sebelumnya melakukan uji confirmatory factor analysis dengan bantuan software LISREL 8.54 pada 209 partisipan. Hasilnya menunjukkan bahwa TAS-20 versi bahasa Indonesia ini valid untuk digunakan dalam konteks Indonesia $(\alpha=0,82)$. Buss-Perry Aggression Questionnaire (BPAQ-29) oleh Buss dan Perry (1992) bertujuan untuk mengukur sifat disposisional agresi dalam aspek kognitif, afektif, dan perilaku (Donahue, dkk., 2014). Pada penelitian sebelumnya pada sampel mahasiswa, nilai koefisien test-retest reliability yang didapatkan ialah 0,90 (Yusainy \& Lawrence, 2014).

\section{Analisis Data}

Analisis data akan dilakukan dengan bantuan program SPSS 22.0 for windows. Uji normalitas menggunakan analisis Kolmogorov-Smirnov karena jumlah sampel yang diatas 100 orang. Dalam penelitian ini, uji normalitas menunjukkan data yang tidak berdistribusi normal sehingga uji korelasi yang akan dilakukan bersifat non-parametrik menggunakan Spearman's Rank Correlation. Uji beda berdasarkan jenis kelamin dilakukan menggunakan teknik Mann-Whitney Test dan uji beda berdasarkan usia dilakukan menggunakan teknik Kruskal-Wallis Test.

\section{HAS I L P E N EL I T IAN}

Hasil analisis deskriptif menunjukkan bahwa partisipan yang tidak mengalami alexithymia ialah sebanyak 57 orang (27,7\%), partisipan yang memiliki skor alexithymia ambang berjumlah 51 orang $(24,8 \%)$, dan partisipan yang memiliki skor alexithymia tinggi ialah sebanyak 98 orang $(47,6 \%)$. Sementara itu, partisipan yang memiliki skor agresivitas rendah berjumlah sebanyak 29 orang (14\%), partisipan dengan skor agresivitas moderat berjumlah 140 orang (68\%), dan partisipan dengan skor agresivitas tinggi berjumlah 37 orang (18\%).

Hasil uji korelasi menunjukkan nilai koefisien korelasi sebesar $r_{s}(204)=0,41, p<0,05$ dan memiliki kekuatan hubungan $\left(r_{s}\right)$ yang berada pada kisaran antara 0,30 - 0,49 yang termasuk kekuatan hubungan yang moderat. Kesulitan mengidentifikasi dan mendeskripsikan emosi (DIF dan DDF) menunjukkan nilai korelasi $p<0,05$ dengan dimensi PA (Physical Agression), Ang (Anger), dan H (Hostility). Dimensi Verbal Agression (VA) menunjukkan korelasi sebesar $p>0,05$ dengan keseluruhan dimensi alexithymia (DIF, DDF, dan EOT). Dimensi EOT menunjukkan korelasi sebesar $p>0,05$ dengan keseluruhan dimensi agresivitas (PA, VA, H, dan Ang). 


\section{I S K U S I}

Berdasarkan hasil penelitian sebelumnya, hubungan yang positif dan signifikan antara alexithymia dan agresivitas pada remaja menunjukkan bahwa remaja yang memiliki kecenderungan alexithymia yang tinggi lebih mungkin untuk mengalami peningkatan agresivitas, begitu pun sebaliknya. Temuan dalam penelitian ini sejalan dengan beberapa penelitian sebelumnya, salah satunya ialah penelitian Janik McErlean dan Lim (2019) serta Li dan kawan-kawan (2020) menemukan bahwa terdapat hubungan positif antara alexithymia dan agresi. Emosi berfungsi menyediakan informasi untuk mengarahkan, mengontrol, dan meregulasi perilaku yang sejalan dengan norma sosial. Namun, individu yang mengalami alexithymia seringkali tidak sadar atau kebingungan akan emosi yang dirasakan beserta penyebabnya. Kesulitan dalam mengekspresikan perasaan tersebut dapat membuat individu mengalami frustrasi atau distres internal sehingga gagal mengatur emosi secara adaptif dan berujung pada munculnya masalah perilaku (Konrath dkk., 2012; Aricak \& Ozbay, 2016; Li, dkk., 2020).

Secara umum, bentuk perilaku agresif memang dapat disebabkan oleh adanya afek negatif, seperti kemarahan. Akan tetapi, tidak selamanya kemarahan terwujud dalam perilaku agresi karena masih bergantung pada apa yang dilakukan terhadap afek negatif tersebut (Aeni, 2011). Dalam hal ini, keterampilan emosional individu memainkan peran penting. Keterampilan emosional yang baik membuat individu dapat mengendalikan perasaan dan mampu mengungkapkan reaksi emosi sesuai dengan waktu dan kondisi yang ada sehingga tidak mudah meluapkan energinya ke arah perilaku yang merugikan diri sendiri maupun orang lain.

Seperti yang kita ketahui, masa remaja dipandang sebagai tahap perkembangan emosional masih berada dalam proses pematangan dan dapat mengarah ke berbagai gaya dan metode ekspresi emosi pada masing-masing remaja. Remaja seringkali sulit menunjukkan, mengkontrol, dan mengatur emosinya sehingga membuat remaja menggunakan mekanisme koping untuk meredam emosinya secara maladaptif, salah satunya agresi. Periode pematangan emosional yang kurang sukses inilah yang dapat membuat remaja rentan terhadap banyak masalah kesehatan mental yang lebih berat, salah satunya alexithymia (Sfeir dkk., 2020). Honkalampi, dkk. (2009) menemukan bahwa remaja yang mengalami alexithymia memiliki masalah internal dan masalah perilaku eksternal yang lebih tinggi, seperti gejala depresi, menarik diri, perilaku agresif, masalah perhatian, penggunaan alkohol yang maladaptif, serta masalah dalam hubungan sosial termasuk di rumah dan di sekolah.

Dimensi kesulitan memahami emosi (DIF) dan mengkomunikasikan emosi (DDF) pada alexithymia dapat mempengaruhi kemunculan agresi fisik, amarah, dan sikap permusuhan, sedangkan ketiga dimensi alexithymia (DIF, DDF, EOT) tidak berhubungan signifikan dengan agresi verbal. Dimensi DIF pada alexithymia paling berkorelasi dengan dimensi Hostility pada agresivitas. Hasil tersebut menunjukkan bahwa individu yang mengalami alexithymia, khususnya ketika sulit memahami emosi secara covert lebih dominan menunjukkan sikap permusuhan daripada rasa marah, serta secara overt cenderung berperilaku agresif secara fisik. Nilai yang tidak signifikan antara ketiga dimensi alexithymia dengan Agresi Verbal (VA) dapat disebabkan karena individu alexithymia cenderung langsung bertindak dengan melakukan perkelahian fisik terhadap orang lain agar orang tersebut dapat memahami pikiran atau perasaannya tanpa harus mengkomunikasikannya secara verbal. Selain itu, cara tersebut dapat dianggap sebagai cara yang paling tepat dan efektif agar orang lain dapat memahami dirinya ketika merasa buruk (Margolin, dkk., 2002). 
Sementara itu, kecenderungan individu untuk berfokus pada hal-hal eksternal dan mengabaikan pengalaman emosi dalam diri (EOT) tidak mempengaruhi kemunculan agresivitas pada individu, terutama pada munculnya rasa marah. Hal ini dapat disebabkan karena pemikiran berorientasi eksternal yang ditandai dengan pengabaian akan emosi dalam diri memungkinkan seseorang untuk melindungi kondisi mental akan efek buruk dari rasa marah tersebut sehingga dapat mencegahnya untuk berperilaku agresif (Larionov \& Grechukha, 2020).

\section{S I M P U L A N}

Kesimpulan dari penelitian ini ialah terdapat korelasi yang signifikan, positif, dan moderat antara alexithymia dan agresivitas pada usia remaja. Hasil penelitian ini menunjukkan bahwa seorang remaja yang memiliki kecenderungan alexithymia yang tinggi terutama kesulitan dalam mengidentifikasi emosi, lebih mungkin untuk mengalami peningkatan agresivitas, khususnya pada aspek sikap permusuhan, begitu pun sebaliknya.

Berdasarkan implikasi dan keterbatasan penelitian, saran penelitian selanjutnya antara lain menambah jumlah partisipan serta menyeimbangkan jumlah partisipan laki-laki dan perempuan untuk mendapatkan hasil yang lebih representatif. Penelitian selanjutnya juga dapat mempertimbangkan faktor-faktor atau karakteristik sampel yang lain yang mungkin juga berpengaruh terhadap variabel dalam penelitian ini, misalnya depresi atau kecemasan, atau menggunakan sampel remaja yang memiliki masalah kekerasan. Selain itu, penting juga untuk mempertimbangkan konteks kebudayaan masyarakat Indonesia khususnya dalam hal pengungkapan emosi.

\section{U C A P A N TERIMAKASIH}

Terima kasih saya ucapkan kepada Tuhan YME, keluarga, teman-teman, dan pihak-pihak terkait yang telah banyak membantu dan mendukung penulis dalam proses penelitian.

\section{DEKLARASI POTENSI TERJADINYAKONFLIK KEPENTINGAN}

Victora Cindy dan Tri Kurniati Ambarini tidak bekerja, menjadi konsultan, memiliki saham, atau menerima dana dari perusahaan atau organisasi manapun yang mungkin akan mengambil untung dari diterbitkannya naskah ini.

\section{PUSTAKA ACUAN}

Aeni, N. (2011). Perbedaan kecerdasan emosi dan perilaku agresi pada anak yang ditinggal ibu sebagai tkw dengan anak yang tinggal bersama ibunya: studi pada sekolah dasar di kecamatan gabus, kabupaten pati jawa tengah. Widyariset, 14(1), 231-240. Diakses dari http://widyariset.pusbindiklat.lipi.go.id/index.php/widyariset/article/view/409

Aricak, 0. T., \& Ozbay, A. (2016). Investigation of the relationship between cyberbullying, cybervictimization, alexithymia and anger expression styles among adolescents. Computers in Human Behavior, 55, 278-285. https://doi.org/10.1016/j.chb.2015.09.015




Buss, A. H., \& Perry, M. (1992). The Aggression Questionnaire. Journal of Personality, 63(3), 452-459.

de Schutter, M. A. M., Kramer, H. J. M. T., Franken, E. J. F., Lodewijkx, H. F. M., \& Kleinepier, T. (2016). The influence of dysfunctional impulsivity and alexithymia on aggressive behavior of psychiatric patients. Psychiatry Research, 243, 128-134. https://doi.org/10.1016/j.psychres.2016.06.023

Donahue, J. J., Goranson, A. C., McClure, K. S., \& Van Male, L. M. (2014). Emotion dysregulation, negative affect, and aggression: A moderated, multiple mediator analysis. Personality and Individual Differences, 70, 23-28. https://doi.org/10.1016/j.paid.2014.06.009

Evren, C., Cinar, O., Evren, B., Umut, G., Can, Y., \& Bozkurt, M. (2015). Relationship between alexithymia and aggression in a sample of men with substance dependence. Klinik Psikofarmakoloji Bulteni, 25(3), 233-242. https://doi.org/10.5455/bcp.20130408020445

Fitri, N. F., \& Adelya, B. (2017). Kematangan emosi remaja dalam pengentasan masalah. Jurnal Penelitian Guru Indonesia, 2(2), 30-39. Diakses dari https://jurnal.iicet.org/index.php/jpgi/article/view/225

Gillespie, S. M., Garofalo, C., \& Velotti, P. (2018). Emotion regulation, mindfulness, and alexithymia: Specific or general impairments in sexual, violent, and homicide offenders? Journal of Criminal Justice, 58(July), 56-66. https://doi.org/10.1016/j.jcrimjus.2018.07.006

Hemming, L., Haddock, G., Shaw, J., \& Pratt, D. (2019). Alexithymia and its associations with depression, suicidality, and aggression: An overview of the literature. Frontiers in Psychiatry, 10(APR). https://doi.org/10.3389/fpsyt.2019.00203

Honkalampi, K., Tolmunen, T., Hintikka, J., Rissanen, M. L., Kylmä, J., \& Laukkanen, E. (2009). The prevalence of alexithymia and its relationship with Youth Self-Report problem scales among Finnish adolescents. Comprehensive Psychiatry, 50(3), 263-268. https://doi.org/10.1016/j.comppsych.2008.08.007

Janik McErlean, A. B., \& Lim, L. X. C. (2019). Relationship between parenting style, alexithymia and aggression in emerging adults. Journal of Family Issues. https://doi.org/10.1177/0192513X19886647

Jenkins, M. L. (2018). Alexithymia in minority children: assessment, intervention, and implications. Faculty of the School of Psychology \& Counseling Regent University, Disertasi, (May), 1-77.

Konrath, S., Novin, S., \& Li, T. (2012). Is the relationship between alexithymia and aggression contextdependent? Impact of group membership and belief similarity. Personality and Individual Differences, 53(3), 329-334. https://doi.org/10.1016/j.paid.2012.04.004

Larionov, P. M., \& Grechukha, I. A. (2020). The role of alexithymia and cognitive emotion regulation in the development of aggressive behavior in adolescents. Clinical Psychology and Special EduсаtionКлиническая и Спещиальная Психология, 9(4), 57-98. https://doi.org/10.17759/cpse.2020090404

Li, X., Li, B., Lu, J., Jin, L., Xue, J., \& Che, X. (2020). The relationship between alexithymia, hostile attribution

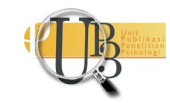


bias, and aggression. Personality and Individual Differences, 159(December 2019). https://doi.org/10.1016/j.paid.2020.109869

Margolin, A., Youga, J., \& Ballou, M. (2002). Voices of violence: A study of male adolescent aggression. The Journal of Humanistic Counseling, Education and Development, 41(2), 215-231. https://doi.org/10.1002/j.2164-490x.2002.tb00144.x

Merdekasari, A., \& Chaer, M. T. (2017). Perbedaan perilaku agresi antara siswa laki-laki dan siswa perempuan di SMPN 1 Kasreman Ngawi. Jurnal Psikologi Pendidikan Dan Konseling: Jurnal Kajian Psikologi Pendidikan Dan Bimbingan Konseling, 3, 53. https://doi.org/10.26858/jpkk.v0i0.2996

Ng, C. S. M., \& Chan, V. C. W. (2020). Prevalence and associated factors of alexithymia among Chinese adolescents in Hong Kong. Psychiatry Research, 290(March), 113126. https://doi.org/10.1016/j.psychres.2020.113126

Nurfitria, S., \& Machsunah, I. I. (2019). Keterkaitan Alexithymia dengan perilaku agresif pada remaja lakilaki. Proceedings of the ICECRS, 2(1), 89. https://doi.org/10.21070/picecrs.v2i1.2411

Rinanda, F. Z., \& Haryanta. (2017). Hubungan Antara kecerdasan emosi dengan agresivitas pada atlet futsal. Gadjah Mada Journal of Psychology (GamaJoP), 3(1), 37. https://doi.org/10.22146/gamajop.42398

Roberton, T., Daffern, M., \& Bucks, R. S. (2012). Emotion regulation and aggression. Aggression and Violent Behavior, 17(1), 72-82. https://doi.org/10.1016/j.avb.2011.09.006

Sfeir, E., Geara, C., Hallit, S., \& Obeid, S. (2020). Alexithymia, aggressive behavior and depression among Lebanese adolescents: A cross-sectional study. Child and Adolescent Psychiatry and Mental Health, 14(1), 1-7. https://doi.org/10.1186/s13034-020-00338-2

SNPK. (2015). Laporan Bulanan Bulan Maret 2015. Diakses dari http://snpk.kemenkopmk.go.id/

Taylor, G. J., Parker, J. D., \& Bagby, R. M. (1999). Alexithymia: Concept, measurement, and implications for treatment. American Journal of Psychiatry, 141(6), 725-732. https://doi.org/10.1176/ajp.141.6.725

Teten, A. L., Miller, L. A., Bailey, S. D., Dunn, N. J., \& Kent, T. A. (2008). Empathic deficits and alexithymia in trauma-related impulsive aggression. Behavioral Sciences \& the Law, 26, 823-832. https://doi.org/10.1002/bsl

Winter, K., Spengler, S., Bermpohl, F., Singer, T., \& Kanske, P. (2017). Social cognition in aggressive offenders: Impaired empathy, but intact theory of mind. Scientific Reports, 7(1), 1-11. https://doi.org/10.1038/s41598-017-00745-0

Yusainy, C., \& Lawrence, C. (2014). Relating mindfulness and self-control to harm to the self and to others. Personality and Individual Differences, 64, 78-83. https://doi.org/10.1016/j.paid.2014.02.015 